\title{
Predicting Species Distribution for True Indigo (Indigofera tinctoria L.) in Citarum Watershed, West Java, Indonesia
}

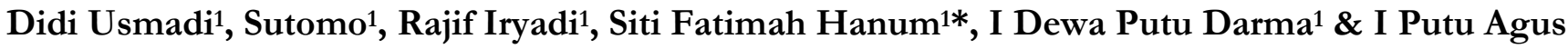 \\ Hendra Wibawa ${ }^{1}$ \\ 1) Research Centre for Plant Conservation and Botanical Garden: Reintroduction and Spatial Ecology Research Group- Indonesian \\ Institute of Sciences (LIPI) \\ * Corresponding author, email: sitifatimahhanum2004@yahoo.com
}

Submitted: 20 April 2021; Accepted: 12 July 2021; Published online: 20 September 2021

\begin{abstract}
Citarum watershed is a region of approximately $6,610 \mathrm{~km}^{2}$ in West Java, Indonesia. Citarum watershed has been degraded through historical land use and vegetation clearing. Rehabilitation of Citarum watershed uses Indigofera tinctoria L. that has value as a source of natural blue dye and is considered suitable for the region. Species distribution modelling and Habitat suitability index (SDM/HSI) were undertaken for I. tinctoria. The occurrence and environment data (bioclimatic, topography, and soil type) were input to HSI. Results of the Indigofera tinctoria habitat suitability model in Citarum watershed are very good (0.9-1) for some parts of the Citarum watershed. The medium and high suitability areas were respectively $4.49 \%$ and $4.37 \%$ of the area were located in the lowlands (Bekasi Regency and Karawang Regency). Prediction based on climate modelling for 2050 and 2070 estimated that the medium-high suitability area of Indigofera tinctoria will be reduced relative to the present.
\end{abstract}

Keywords: bioclimatic, modeling, natural, suitability

\section{INTRODUCTION}

True indigo (Indigofera tinctoria L.) belongs to the Fabaceae family. True indigo is known as the world's oldest source of natural blue color (Lemmens \& Wulijarni-Soetjipto 1999). Based on Lemmens \& Wessel-Riemens (1992), true indigo originates from Asia, but it is now pantropical due to cultivation. True indigo was widely cultivated in India and Southeast Asia in the 16th century, but its blue dye products have been recorded in Sanskrit data from 4,000 years ago (Lemmens \& Wessel-Riemens 1992). True indigo is an upright and straight small shrub whose height can reach $1.5 \mathrm{~m}$, branching well from the base of the plant. The leaves are imparipinnate and divide like opposite leaflets, are elongated, pubescent, the apex is micronous and the base tapered. Recemes are axillary and multiple, to $5 \mathrm{~cm}$ long and persistent. The petals are pea-form, $1 \mathrm{~cm}$ long and the sepals are hairy. The corolla is tementose and elliptical, and pale pink. The pods are about $3 \mathrm{~cm}$ long, curved in the apical area, otherwise cylindrical, glabrous and the seeds are $2 \mathrm{~mm}$ long. Each cylindrical pod contains about 10 seeds which are greenish gray in 
color (Kumar et al. 2020). The other uses of Indigofera species include cover crops or green manure.

True indigo has been utilised especially livestock feed. The leaves of true indigo have been used for epilepsy and nervous disorders and to heal sores and ulcers in traditional medicine (Lemmens \& Wessel-Riemens 1992).

True indigo is known as tarum in Indonesian. The name tarum comes from the Sundanese language and is known as the "mangsi-mangsian" plant (Ariyanti \& Asbur 2018). The Javanese call it tom. In Bali, it is known as Taum, and was once dominant on the island of Nusa Penida Bali where the center of weaving craftsmen is located. The use of clothing dyes is mainly carried out in making batik or traditional ikat weaving from the archipelago. Apart from being a producer of blue dye, indigo or tarum is also used to produce a green color by combining it with other natural yellow dyes (Ariyanti \& Asbur 2018). In the past, tarum was an inseparable part of Sundanese life. Many places in the West Java region are named after this plant, including Tarumanagara, Banjar Pataruman, Tarumajaya, and the Citarum watershed (Prasetyo 2019).

One of the largest and famous watersheds in West Java is the Citarum. The Citarum watershed has an area of approximately $6,610 \mathrm{~km}^{2}$ with the area covering Bandung, Cimahi, Cianjur, Purwakarta, part of Bogor, part of Bekasi and Karawang (KLHK 2019). Citarum consists of two syllable components in Sundanese which means $\mathrm{Ci}=$ water and Tarum $=$ indigo tree (Indigofera tinctoria) (Prasetyo 2019). The fact of this name indicates that since ancient times (perhaps the 4th century AD) there has been harmonization between rivers (water) and plants/vegetation or in this case the Citarum watershed is the possibility of domination of the species Indigofera tinctoria. Naturally, the quality of the watershed is influenced by soil-forming biophysical factors, namely relief, topography, physiography, climate, soil, water, and vegetation. However, due to various anthropogenic disturbances, the Citarum watershed is currently known as one of the most polluted watersheds in the world.

It is ironic when we see the fact that most of the pollution of Citarum watershed came from a textile producer which uses synthethic colouring. Since 1915, the use of tarum plants as a producer of dyes has been declining and no one is trying to process tarum more easily. Even until now, in the original area of tarum plant itself, namely in Pataruman, the local people no longer recognise the plant. This situation is due to the fact that batik entrepreneurs who initially used natural dyes from tarum plants to dye their batik fabrics switched to synthetic dyes that are considered more practical in their use (Ariyanti \& Asbur 2018). This condition provides a warning for us to be able to act immediately to improve the ecosystem. Pollution is already so severe on agricultural lands that it is feared that it will disrupt food stability or food security. What is most often ignored is the prevalence of land use change and deforestation in the upstream area which exacerbates the sedimentation rate in the downstream and estuary areas, damaging the habitat of flora and can result in loss of species.

This paper analysed the potential distribution of Indigofera tinctoria in Citarum watershed areas specifically and in West Java Province in general to map areas that are suitable (have high habitat suitability index) and can be used to re-introduce Indigofera tinctoria in Citarum watershed and West Java Province as part of its speedy recovery program (Program Percepatan Pengendalian Kerusakan/P3K) as mandated in Presidential Regulation No. 15 of 2018 emphasize the Acceleration of Pollution and Damage Control (P3K) in the Citarum watershed. 


\section{MATERIALS AND METHODS}

This study was located on Citarum watershed, West Java - Indonesia. It has approximately $6,610 \mathrm{~km}^{2}$, of an area with the area covering Bandung, Cimahi, Cianjur, Purwakarta, part of Bogor, part of Bekasi, and Karawang (KLHK 2019) where has the geography location on $5.9107^{\circ}-7.2440^{\circ} \mathrm{S}$ and $106.9640^{\circ}$ $-107.9475^{\circ} \mathrm{E}$ (Figure 1). As a large watershed, Citarum area has large three dams: Jatiluhur, Cirata, and Saguling.

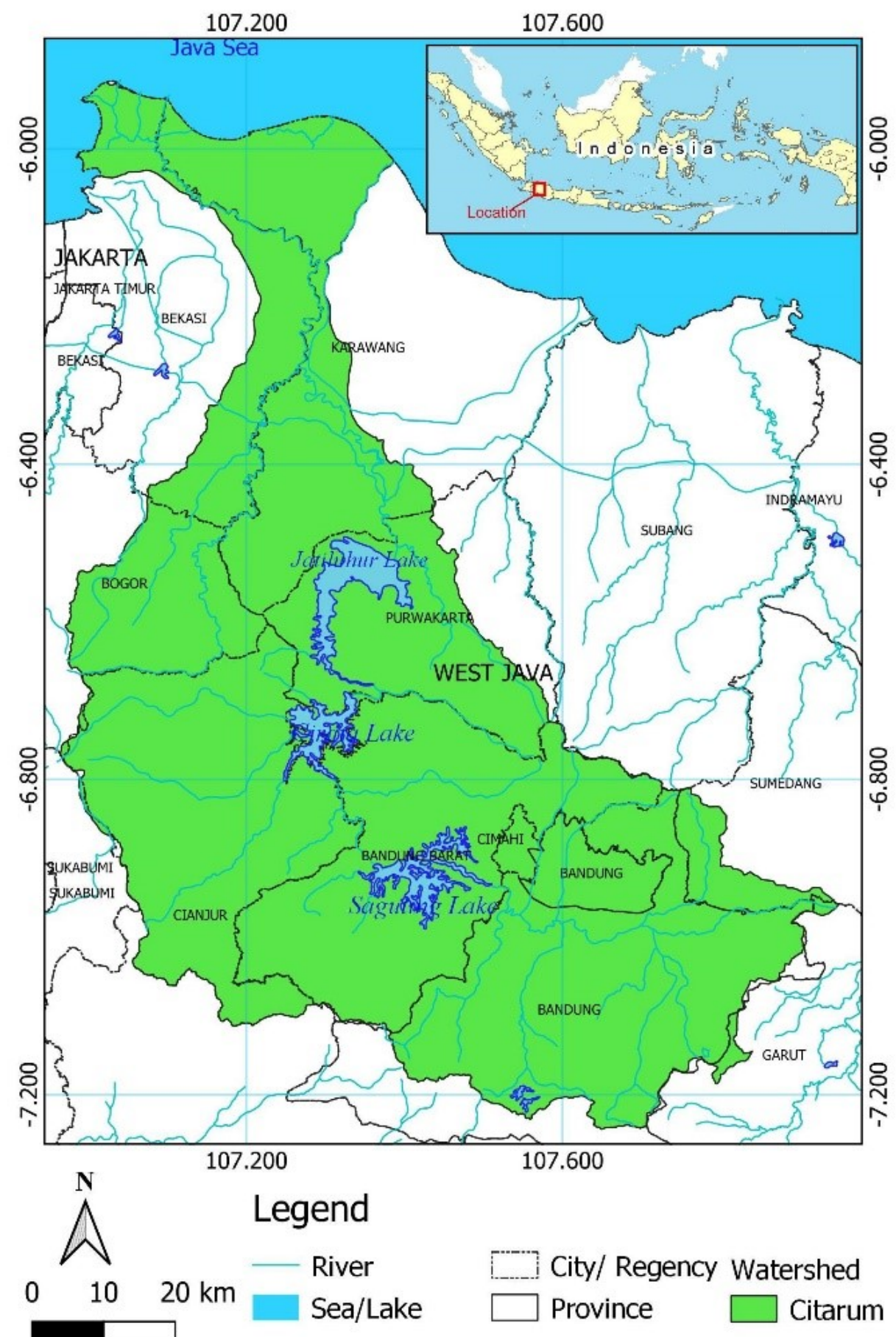

Figure 1. The study area of Citarum watershed, West Java - Indonesia.

Species distribution modelling/Habitat suitability index (SDM/HSI) was done for the targeted species true indigo. Occurrence data of the species obtained from the field as well as its geographic coordinates available in the Global Biodiversity Information Facility (GBIF/www.gbif.org) were used as input layers for the model. There are 1,405 geo-referenced records (worldwide) of this species in the GBIF database record. GBIF records show (based on preserved specimens, observations, and material samples, and 
living specimen) that there was a declining number of records of the species. The occurrence data used in the species distribution model of true indigo is 40 occurrence data in Indonesia.

Environmental variables used to compile the species distribution model of true indigo are bioclimatic, topography, and soil. The bioclimatic variables used WorldClim version 2.1 which is the current data for 19702000. There are 19 bioclimatic variables data with id bio1 to bio19 (Table 1).

Table 1. Details of data obtained from WorldClim Version 2.1. https://www.worldclim.org/data/worldclim21.html

\begin{tabular}{cll}
\hline No & \multicolumn{1}{c}{ Layer data } & \multicolumn{1}{c}{ Content data } \\
\hline 1 & bio1 & Annual mean temperature \\
2 & bio2 & Mean diurnal range \\
3 & bio3 & Isothermality \\
4 & bio4 & Temperature seasonality \\
5 & bio5 & Maximum temperature of warmest month \\
6 & bio6 & Minimum temperature of coldest month \\
7 & bio7 & Temperature annual range \\
8 & bio8 & Mean temperature of wettest quarter \\
9 & bio9 & Mean temperature of driest quarter \\
10 & bio10 & Mean temperature of warmest quarter \\
11 & bio11 & Mean temperature of coldest quarter \\
12 & bio12 & Annual precipitation \\
13 & bio13 & Precipitation of wettest month \\
14 & bio14 & Precipitation of driest month \\
15 & bio15 & Precipitation seasonality \\
16 & bio16 & Precipitation of wettest quarter \\
17 & bio17 & Precipitation of driest quarter \\
18 & bio18 & Precipitation of warmest quarter \\
19 & bio19 & Precipitation of coldest quarter \\
\hline
\end{tabular}

Topography variables use SRTM (Shuttle Radar Topography Mission) data. The topographic variables used were elevation and slope which were downloaded from https://www.earthenv.org/topography. Soil variables used in constructing the model are soil types which were downloaded from http://www.fao.org/soils-portal. All environmental variables have a spatial resolution of $30 \operatorname{arsec}(\sim 1 \mathrm{~km})$. Environmental variables that will be used in compiling the species distribution model were tested for collinearity in the form of paired Pearson correlations between variables. Environmental variables that have a paired Pearson correlation value (r) of more than 0.85 or less than -0.85 , then one of the paired variables must be eliminated (Syfert 2013).

Analysis of the species distribution model using the maximum entropy method (Maxent) using maxent software version 3.4.4. Maxent can model the distribution of species using presence-only datasets, where the target probability distribution is identified based on the optimal convergence at maximum entropy (Phillips et al. 2006). Maxent can combine environmental variables in the form of continuous and categorical data in model analysis (Phillips \& Dudík 2008). The data occurrence species used to build the model (train) is randomly selected $75 \%$ of the data, while $25 \%$ of the data is used for the performance model (test). Model robustness was evaluated using 
the AUC (Area Under the Curve) (Crego et al. 2014). The model performance evaluation uses the Receiver Operating Characteristic (ROC) method. ROC works by comparing sensitivity and 1 -specificity, sensitivity shows how well the model predicts presence, while specificity shows how well the model predicts absence (Phillips et al. 2006), the evaluation results are described in the AUC value (Table 2) (Crego et al. 2014; Sutomo \& van Etten 2017; Ellen et al. 2020).

Table 2. Model performance value.

\begin{tabular}{cc}
\hline AUC Score & Model performance \\
\hline $0.9-1$ & Very good \\
$0.8-0.9$ & Good \\
$0.7-0.8$ & Moderate \\
$0.6-0.7$ & Not good \\
\hline
\end{tabular}

The prediction is visualised as the suitability of a grid cell on a scale from 0 to 1 , where 0 refers to very low suitability and 1 refers to very high suitability (Sutomo \& van Etten 2017; Sutomo et al. 2018). The thresholds used to categorize the suitability area of species are: $0-0.2$, non-suitable area; 0.2-0.4, low-suitability area; 0.4-0.6, general-suitability area; 0.6-0.8, medium -suitability area; and 0.8-1, high-suitability area (Li et al. 2020).

The primary output of a SDM is a map that shows the predicted distribution of I. tinctoria under the baseline conditions. The resulting raster format file was then processed at QGIS 3.16. A baseline map of West Java was added and the Citarum watershed map was also overlaid. It is important to note that this is not a prediction of where the species occurs, but rather the distribution of suitable habitat as defined by the environmental variables (in this case, current climate conditions) included in the model (Hallgren et al. 2016). Future distribution of species using MIROC5 data with scenario Representative Concentration Pathways (RCP) 8.5, projection year is 2050 (average for 2041-2060) and 2070 (average for 2061-2080).

\section{RESULTS AND DISCUSSION}

\section{Variable selection}

Examination of true indigo (Indigofera tinctoria) distribution around the Citarum watershed using Global Biodiversity Information Facility (GBIF) records (based on preserved specimens, observations, and material sample and living specimen) shows a total of 27 recorded Indigofera tinctoria in Java island that there was the declining number of records of the species (GBIF Secretariat 2021). Based on record data on these periodically, in 1829-1940 in total there are twenty-two records, in 1848-1950 four records, and since 1959 up to 2020 there was one record of this species.

Environmental variable selection is only performed on continuous environmental data (bioclimatic and topography), while soil data is not selected because it is categorical data. The results of the collinearity analysis show that several pairs of environmental variables have a Pearson correlation that is more than 0.85 or less than -0.85 (Table 3 ), so that some of these environmental variables are eliminated. The results of the analysis show that the environmental variables that will be used in constructing the species distribution model are 12 variables, namely: 2 topographic variables (elevation and slope), 1 soil variable (soil type), and 9 bioclimatic variables (number 2,3,7,12,13,14,15,18 and 19) (Tabel 1.) 


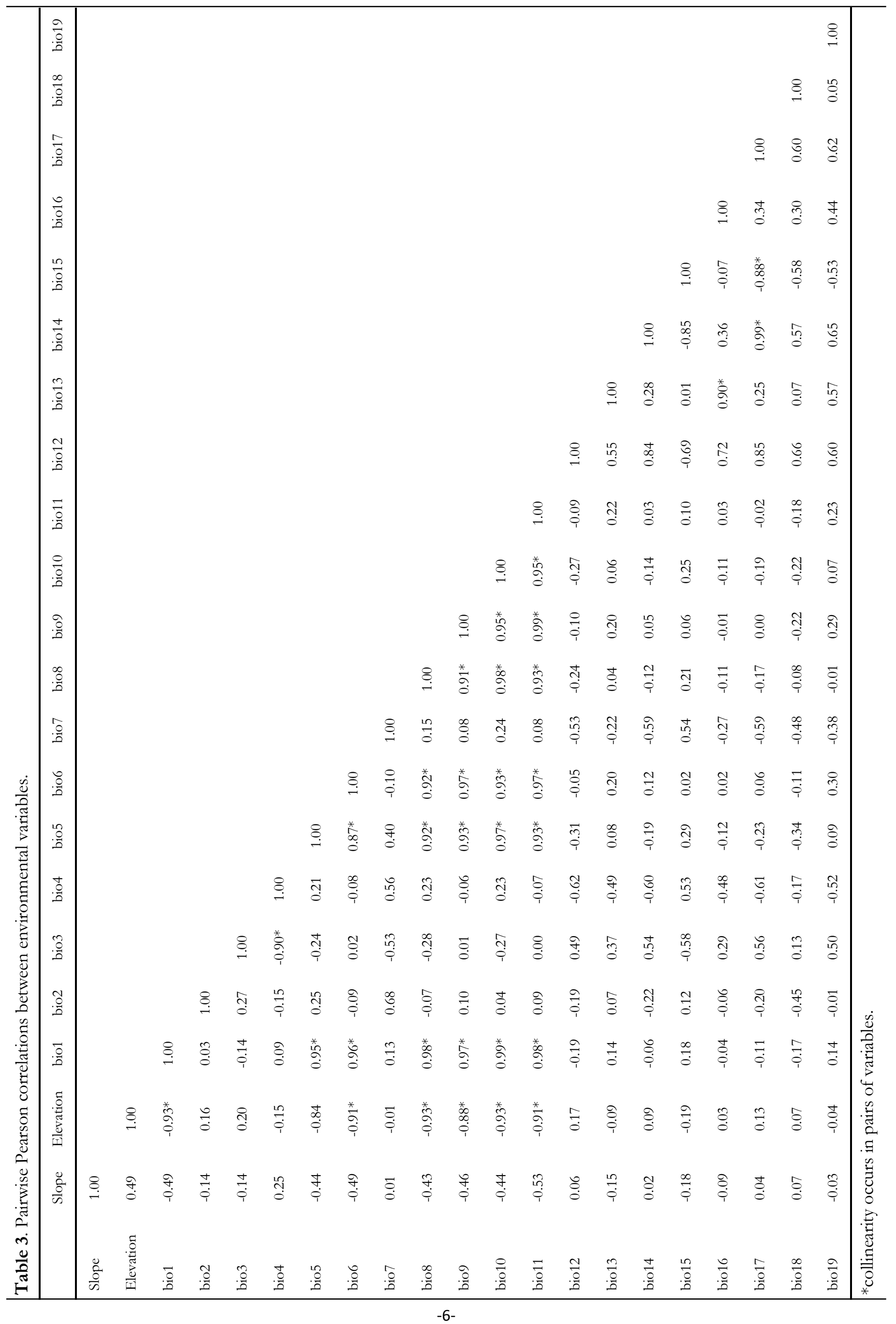




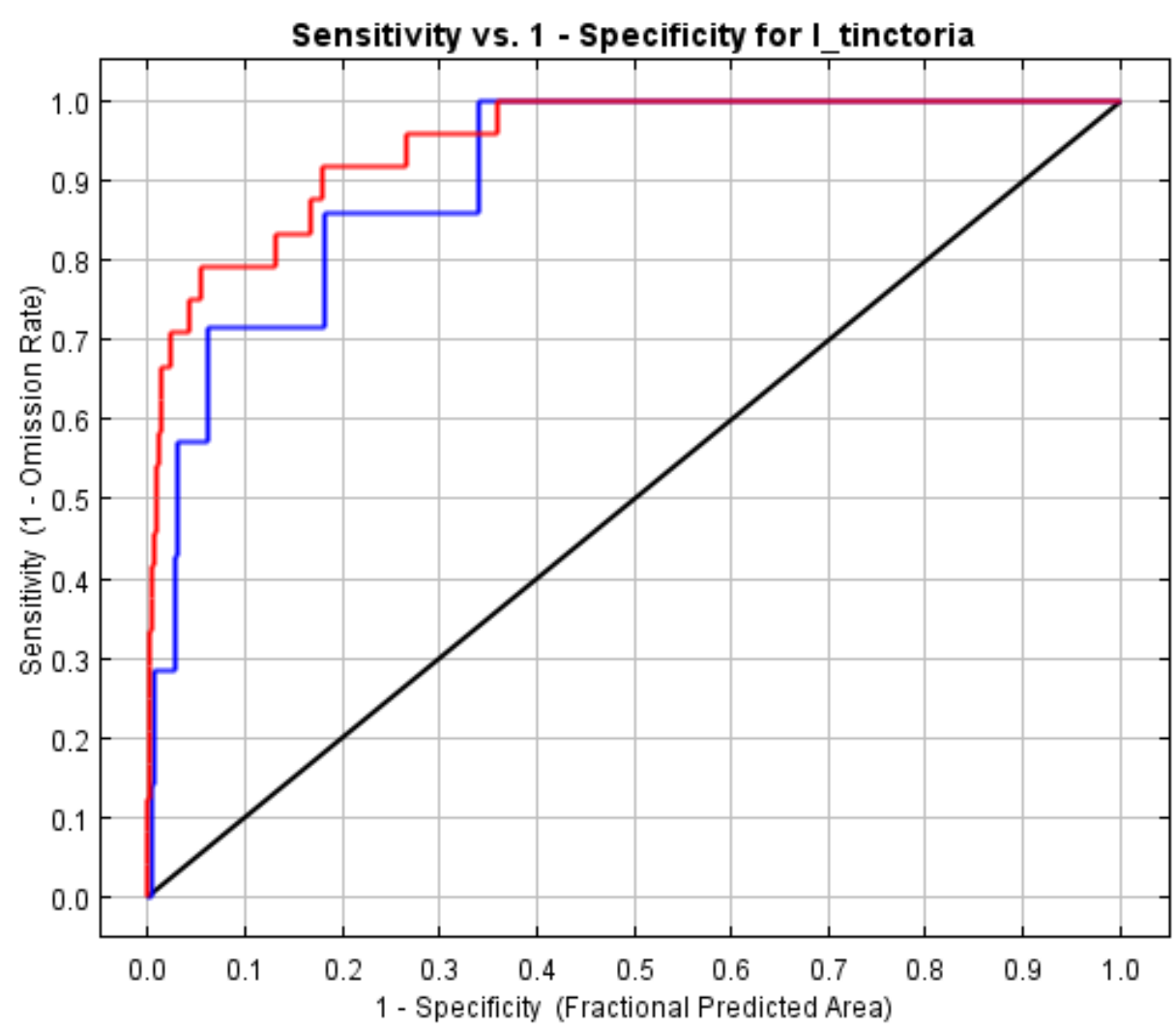

Training data $(\mathrm{AUC}=0.946)$

Test data $(A \cup C=0.907)$

Random Prediction (AUC $=0.5)$

Figure 2. Receiver Operating Characteristic Curve plot habitat suitability model for Indigofera tinctoria in Citarum watershed.

\section{Performance Model}

The results of the model performance evaluation are represented in the AUC value. Based on the AUC value, the Indigofera tinctoria habitat suitability in DAS Citarum is modelled as 'very good' because it is in the value range 0.9-1 (AUC training data $=0.946$ and AUC test data $=0.907$ ) (Figure 2). The thin black line on the ROC curve shows the random model AUC, over the grey line, which indicates the better the model's performance is in predicting the presence of samples in the data.

\section{Variable contribution and Importance}

The maxent analysis shows that the highest relative contribution of environmental variables in the making of maxent model is bio14 (precipitation of driest month) with a contribution value of $30.73 \%$. Other environmental variables that have a high contribution are the precipitation seasonality, the precipitation of the warmest quarter, and slope. The variables of precipitation of the wettest month, the precipitation of the coldest quarter, and the temperature annual range have a very low contribution with a contribution value of less than $1 \%$ (Table 4).

Variables that affect the distribution of species can be seen from the value of training gain and AUC with only the following variables. The variables of annual precipitation, the precipitation of the driest month, precipitation seasonality, and the precipitation of the warmest quarter have high training gain and AUC with only these variables compared to all other variables (Table 4). This indicates that these variables are important in modeling to predict these species distributions. The results of the model analysis show that the bioclimatic variables have a major role to predict the species distribution when compared to topography and soil factors.

However, it can be understood that the elevation factor also has an influence on the climatic conditions of a region. 
Table 4. Variable contribution and Importance.

\begin{tabular}{lcccc}
\hline \multicolumn{1}{c}{ variables } & Contribution $(\%)$ & permutation importance & Training gain with only & AUC with only \\
\hline Soil & 6.50 & 2.27 & 0.44 & 0.79 \\
Elevation & 7.39 & 9.08 & 0.31 & 0.77 \\
Slope & 15.12 & 28.39 & 0.34 & 0.77 \\
Bio2 & 1.10 & 0.00 & 0.02 & 0.53 \\
Bio3 & 3.42 & 6.29 & 0.45 & 0.71 \\
Bio7 & 0.00 & 0.00 & 0.33 & 0.67 \\
Bio12 & 3.59 & 48.55 & 0.80 & 0.79 \\
Bio13 & 0.65 & 4.39 & 0.01 & 0.67 \\
Bio14 & 30.73 & 0.00 & 0.91 & 0.84 \\
Bio15 & 18.31 & 0.24 & 1.00 & 0.84 \\
Bio18 & 13.00 & 0.08 & 0.95 & 0.76 \\
Bio19 & 0.19 & 0.69 & 0.22 & 0.73 \\
\hline
\end{tabular}

The characteristics of true indigo habitat can be seen through the variable response curve from the modeling results. The response curve describes the response to the presence of true indigo to environmental variables (Figure 3). Based on the results in the response curve, true indigo generally grows in habitats with a mean diurnal range/mean of monthly temperature (bio2) between $5.8-11.6^{0} \mathrm{C}$. This means that the higher the mean diurnal range, the higher the presence of true indigo in that habitat. True indigo grew in habitats with isothermality index value (bio3) of 64-95 with a mean value of 86 . True indigo is generally found in the lowlands and mostly grows in areas with an altitude of less than $50 \mathrm{~m}$ asl with a slope of $0-18^{0}$. This means that the higher the altitude and slope, the lower the presence of true indigo in these areas.

True indigo seems to prefer habitat with annual precipitation (bio12) between $800-5600 \mathrm{~mm}$ per year with precipitation of driest month (bio14) ranging from $0-300 \mathrm{~mm}$ per month. The suitable habitat for true indigo with a logistic output value $\geq$ of 0.6 is a location with a mean diurnal range of more than $7.8^{\circ} \mathrm{C}$, isothermality index of $77-90$, elevation less than $50 \mathrm{~m}$ asl, slopes less than $5^{0}$, annual precipitation less than $1800 \mathrm{~mm}$ per year, and precipitation of driest month of less than $30 \mathrm{~mm}$ per month.

It is rare to find literature on the natural habitat environmental conditions for the growth and distribution of true indigo. However, several literatures found do match our model results. True indigo grows from lowland up to 300-400 $\mathrm{m}$ above sea level (Kumar et al. 2020). Hariri et al. (2017) report a collection of true indigo samples from locations from 7-343 $\mathrm{m}$ asl in Java and Madura Island. True indigo is intolerant to high variability in precipitation rate (Ariyanti \& Asbur 2018) and waterlogging (Lemmens \& Wessel-Riemens 1992). True indigo also can be found naturally on riverbanks which can explain the presence and abundance of this plant in the past on Citarum watershed.

\section{Current Distribution Species}

The result of true indigo habitat suitability modeling result in Citarum watershed can be seen in figure 4 . These results indicate that many parts of Citarum watershed are suitable for true indigo, but with different suitability indexes. Most of the Citarum watershed area is non-suitable (an area of 4,645 $\mathrm{km}^{2}$ or $70.27 \%$ of the Citarum watershed) area and low suitability area of $1,024 \mathrm{~km}^{2}$ (or $15.49 \%$ of the Citarum watershed) (Table 5). Locations with non-suitable and low suitability areas are generally located in locations with 

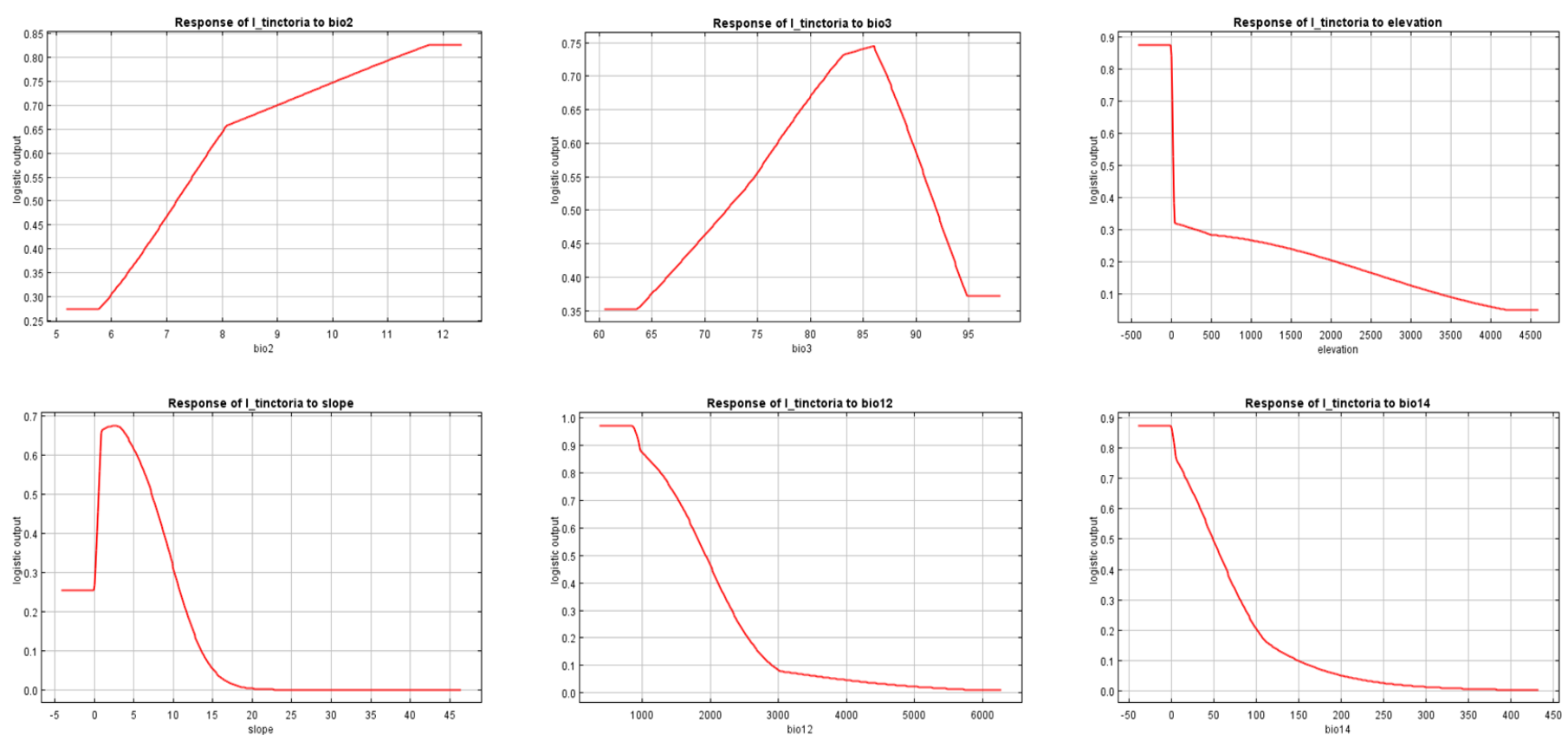

Figure 3. Response curve of the environmental variables that were included in the model.

\section{Current Suitability}
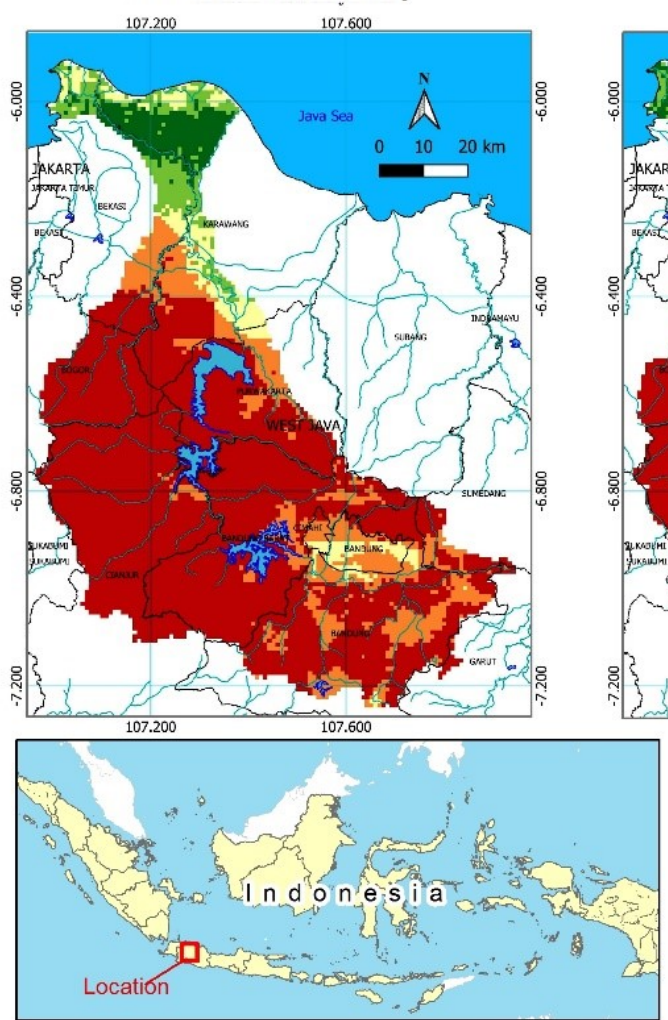

Suitability in $\mathbf{2 0 5 0}$

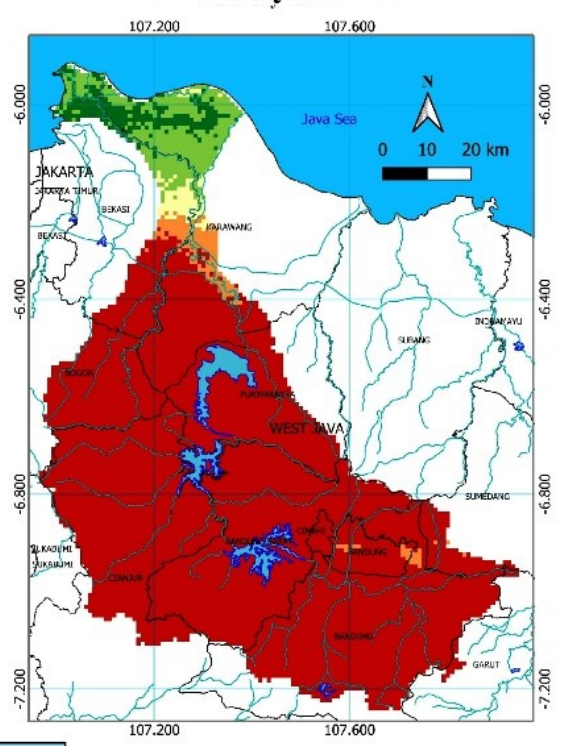

Legend

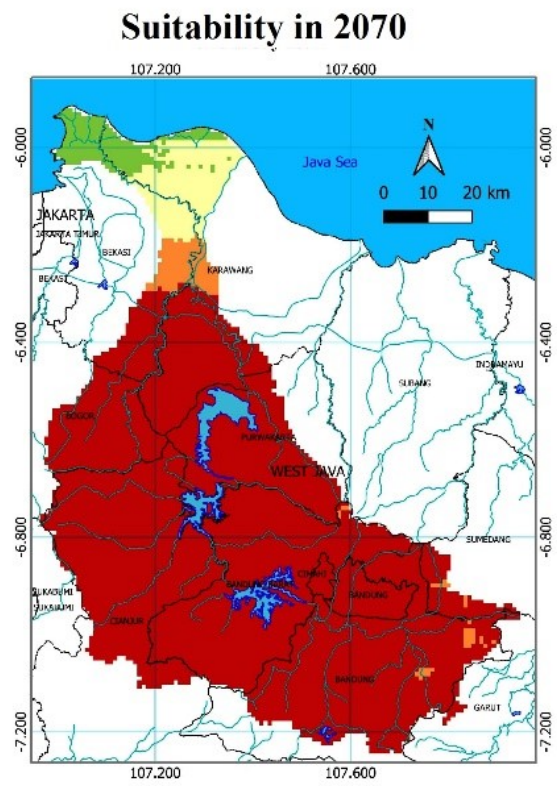

- River

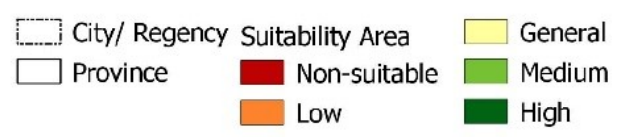

Figure 4. Habitat Suitability Index (HIS) maps show current and future species distribution maps of true indigo in Citarum watershed West Java.

high altitudes, mountains, and hills. These habitats are located in Bandung, West Bandung Regency, Sumedang Regency, Cianjur Regency, Purwakarta Regency, Bogor Regency, part of Bekasi Regency and part of Karawang Regency. The medium and high suitability areas were respectively $4.49 \%$ and $4.37 \%$ of the Citarum watershed area. Generally, this area is located in the lowlands which include part of Bekasi Regency and part of Karawang Regency. 
The results of this study cannot yet concluded if a location with low habitat suitability means that there is no true indigo presence in that location, this is because the modeling only uses species presence data to build the model. In addition, field survey efforts are needed to determine the existence of the species. Location of additional populations would allow for refinement of the model specific to the Citarum watershed. However, the results of this study could be important for the conservation and reintroduction program of the species in the framework of the speedy recovery of the Citarum watershed. Reintroduction of true indigo species could benefit from the habitat suitability map (HIS) map which acts as an indicator of locations that have suitable environmental conditions for the growth of true indigo.

\section{Future Distribution Species}

Changes in the suitability habitat of true indigo geographically in the RPC 8.5 scenario in 2050 and 2070 are presented in figure 4 while the change in area is presented the Table 5. In 2050, high suitability area is estimated to decline by $1.3 \%$ while medium suitability area is estimated to increase by $0.85 \%$. The increase of medium suitability areas is due to the reduction in the suitability area from high to medium. In 2050 the total area of low suitability and nonsuitable area is estimated to increase by $4.6 \%$ over the current year.

In 2070 the medium suitability area of true indigo is estimated to decline by $1.01 \%$, while high suitability areas of true indigo is estimated to decline by $4.35 \%$ over the current year. In 2070 it is estimated that medium and high suitability areas of true indigo will only be in a small part of the Bekasi Regency and Karawang Regency. The reduction in suitability area indicates that the true indigo population is predicted to decrease in the future due to climate change.

\section{CONCLUSION}

In conclusion, currently, true indigo or tarum or I. tinctoria has small areas of suitability index across the Citarum watershed. Sadly, the future projection of the high suitability areas for true indigo also declining from $3.07 \%$ out of the Citarum watershed in 2050 to only $0.02 \%$ in 2070 . We suggest that the results of this study can be useful for the conservation of the Citarum watershed's vegetation especially in the reintroduction efforts of the true indigo (I. tinctoria). Areas with high suitability index from the model can be used as priority areas for establishing plots for reintroduction studies and areas with low suitability might be improved through restoring ecological functions.

Table 5. Current and future suitability habitat of true indigo in Citarum watershed.

\begin{tabular}{lcccccc}
\hline \multirow{2}{*}{ Suitability area } & \multicolumn{2}{c}{ Current } & \multicolumn{2}{c}{$\mathbf{2 0 5 0}$} & \multicolumn{2}{c}{$\mathbf{2 0 7 0}$} \\
\cline { 2 - 7 } & $\mathrm{km}^{2}$ & $\%$ & $\mathrm{~km}^{2}$ & $\%$ & $\mathrm{~km}^{2}$ & $\%$ \\
\hline non-suitable & 4,645 & 70.27 & 5,831 & 88.21 & 5,855 & 88.58 \\
low & 1,024 & 15.49 & 142 & 2.15 & 174 & 2.63 \\
general & 356 & 5.39 & 82 & 1.23 & 350 & 5.29 \\
medium & 297 & 4.49 & 353 & 5.34 & 230 & 3.48 \\
high & 289 & 4.37 & 203 & 3.07 & 1 & 0.02 \\
Total & 6,610 & 100 & 6,610 & 100 & 6,610 & 100 \\
\hline
\end{tabular}




\section{AUTHORS CONTRIBUTION}

We declare that S., D.U., and R.I. are the main contributor whereas S.F.H., I.D.P.D., and I.P.A.H.W. are member contributors of this paper. S. designed the research, wrote down in almost all section of the paper. D.U. designed and wrote the method and results sections. R.I. analyses the data and added in the discussion. S.F.H. added in the discussion. I.D.P.D. added in the introduction and discussion. I.P.A.H.W. added in the introduction.

\section{ACKNOWLEDGMENTS}

We thank the Deputy for Earth Science, Indonesian Institute of Sciences (LIPI) to fund this research.

\section{CONFLICT OF INTEREST}

We declare that there are no conflicts of interest regarding this research or the research funding.

\section{REFERENCES}

Ariyanti, M, \& Asbur, Y., 2018. Tanaman tarum (Indigofera tinctoria Linn.) sebagai penghasil zat pewarna. Jurnal Hutan Pulau-Pulau Kecil, 2(1), pp.109-122.

Crego, R.D., Nielsen, C.K. \& Didier, K.A., 2014. Climate change and conservation implications for wet meadows in dry Patagonia. Environmental Conservation, 41(2), pp.122-131.

Ellen, A., Nasihin, I. \& Supartono, T., 2020. Pemetaan Kesesuaian Habitat Rafflesia (Rafflesia arnoldii R. Br) di Taman Nasional Bukit Barisan Selatan. Prosiding Fabutan, 1(01).

GBIF Secretariat, 2021. Indigofera tinctoria L. (Publication no. Checklist dataset https://doi.org/10.15468/39omei ), viewed 30 June 2021, from GBIF Backbone Taxonomy.

Hallgren, W. et al., 2016. The Biodiversity and Climate Change Virtual Laboratory: Where ecology meets big data. Environmental Modelling \& Software, 76, pp.182-186.

Hariri, M.R., Chikmawati, T. \& Hartana, A., 2017. Genetic diversity of Indigofera tinctoria L. in Java and Madura islands as natural batik dte based on intersimple sequence repeat markers. Journal of Mathematical and Fundamental Sciences, 49(2), pp.105-115.

KLHK, 2019. Mengenal status dan arahan pengelolaan jasa lingkungan DAS Citarum. in Berita Pusat Pengendalian Pembangunan Ekoregion Jawa, viewed 26 july 2021, from http://p3ejawa.menlhk.go.id/news146mengenal-status-dan-arahan-pengelolaan---jasa-lingkungan-dascitarum.html

Kumar, D. et al., 2020. Ethnobotanical and pharmacological review on Indigofera tinctoria. International Research Journal of Pharmaceutical and Applied Sciences, 10(1), pp.1-6.

Lemmens, R.H.M.J. \& Wessel-Riemens, P.C., 1992, 'Indigofera L.' in Lemmens and Wulijarni-Soetjipto, N (Editors), Plant Resources of Southeast Asia 3, Dye and Tannin-Producing Plants, PROSEA foundation, Bogor.

Lemmens, R., \& Wulijarni-Soetjipto, N., 1999, Sumber Daya Nabati Asia Tenggara, No. 3, Tumbub-Tumbuhan Penghasil Pewarna dan Tanin, PT Balai Pustaka, Jakarta bekerja sama dengan Prosea Indonesia, Bogor.

Li, L. et al., 2020. Optimized Maxent Model Predictions of Climate Change Impacts on the Suitable Distribution of Cunninghamia lanceolata in China. Forests, 11, p.302. 
Phillips, S.J., Anderson, R.P. \& Schapire, R.E., 2006. Maximum entropy modelling of species geographic distributions. Ecological Modelling, 190, pp.231-259.

Phillips, S.J. \& Dudík, M., 2008. Modeling of species distributions with Maxent: new extensions and a comprehensive evaluation. Ecography, 31, pp.161-175.

Prasetyo, F.A., 2019. Bandung dan Pemaknaan Dago dalam Sejarah: Masa Lalu, Masa Kini. Lembaran Sejarah, 15(1), pp.64-90.

Sutomo \& van Etten, E., 2017. Species distribution model of invasive alien species Acacia nilotica for Central-Eastern Indonesia using Biodiversity Climate Change Virtual Laboratory (BCCVL). Tropical Drylands, 1(1), pp.36-42.

Sutomo et al., 2018, Ecology of Bedugul Basin Bali. Bogor: SEAMEO BIOTROP.

Syfert, M.M., Smith, M.J. \& Coomes, D.A., 2013. 'The Effects of Sampling Bias and Model Complexity on the Predictive Performance of MaxEnt Species Distribution Models' PLoS ONE, 8(2), e55158 in eventrelated EEG potentials: Are impulsive individuals augmenters or reducers?, Zeitschrift fürdifferentielle und diagnostische Psychologie, 21, pp.208-217. 